\title{
THE ROLE OF OUTPUT AND FEEDBACK IN SECOND LANGUAGE ACQUISITION: A CLASSROOM-BASED STUDY OF GRAMMAR ACQUISITION BY ADULT ENGLISH LANGUAGE LEARNERS
}

\author{
Ewa Donesch-Jezo \\ Jagiellonian University
}

\begin{abstract}
Second language acquisition (SLA) has been a concern of many teachers and researchers since the early 1960s. One of the issues related to SLA has been finding the techniques which effectively focus the learners' attention on the target form. A number of theories and methods have been advocated for this purpose, ranging from implicit options to more explicit ones. Although each of the suggested methods has its own advantages, they have, so far, proved insufficient to get learners to be able to notice the gap between their own interlanguage forms and the target language forms. Swain $(1995,1998)$ has argued that apart from providing the learners with comprehensible input, comprehensible output also plays a beneficial role in L2 acquisition. By encouraging the learners to speak or write in the L2 and providing them with the opportunities to do so, the learners can notice that they are not able to say what they want to say in the target language. On the basis of Swain's output hypothesis, we assumed that encouraging adult learners (university students) to produce target-like output would promote their achievement of the grammatical competence necessary for producing academic tests. The purpose of this article is to present the evidence from a classroom-based, small-scale study of the effect of output on learner acquisition of L2 modal verbs, adjectives and adverbs conveying the meanings of uncertainty, all of which are parts of speech that are important metadiscourse items. The results of the present study suggest that an approach in which students are encouraged to produce comprehensible output, combined with their being provided with learning reinforcement ensured by appropriate feedback, can be an effective source of establishing long-lasting grammatical accuracy in the students' target language.
\end{abstract}

Keywords: L2 acquisition, output, feedback, grammatical accuracy, metadiscourse, consciousness raising 


\section{Introduction}

In order to teach a second/foreign language effectively, every teacher should be aware how it is acquired by the learners. Our knowledge about how learners acquire a second language (also referred to as L2) has developed extensively in the past 40-50 years. Its development has been related to the growth of media technology and the world being seen as a "global village" and also to the introduction of the World Wide Web, all of which have led to a change of attitude to the learning of an L2. Learning a foreign language has no longer been seen as being a kind of pastime or hobby, but rather as a means of obtaining education and/or a better job. Therefore, the understanding of the process of second language acquisition and the methods necessary to adopt for a maximization of its effectiveness have been in the centre of attention of a number of researchers and teachers alike (Ellis 1997: 3). In this context, the meaning of the term second language acquisition (SLA) needs careful explanation. Second language acquisition refers to the process of the learning of a non-native language after the native language has been acquired. Thus a second language may mean a third or fourth language, which is not necessarily contrasted with a foreign language, and this language may be learned in a formal and systematic way (in a classroom) or in an informal and unsystematic way (outside a classroom) or in a combination of both (Mitchell and Myles 2004: 5).

This search for the most effective methodology for SLA has resulted in a growing body of empirical studies and theories based on them, and these have given rise to the implementation of various pedagogical methods advocated by researchers. These methods range from implicit ones, that is, ones without any conscious instruction on the language system, such as input flooding (Krashen 1985), and input enhancement (Lightbown and Spada 1990, Sharwood-Smith 1993, White 1991, 1998) to explicit ones, based on providing conscious instruction on the form, meaning and function of grammatical structures, which include direct rule explanations (DeKeyser 1998, 2007), consciousness-raising procedures (Sharwood-Smith 1981, 1993), and metalinguistic explanatory feedback (Pica et al. 1987, Gass and Mackey 2007).

In all current theories on second language learning, comprehensible input is seen as being the sine qua non of L2 
acquisition. It means that the language which the learner is exposed to (e.g. in the texts he or she is provided with for reading or listening) is a fundamental component of the learning process, as it contains and provides all the necessary evidence from which learners can form linguistic hypotheses (VanPatten and Williams 2007: 177).

The most influential propagator of the crucial role of input in SLA was Stephen Krashen $(1982,1985,1998)$. The basic claim of Krashen's "Input Hypothesis" (1985) was that the provision and availability of input which is comprehensible to the learner, and which is just beyond the learner's current second language competence $(i+1)$, is the only necessary condition for language learning - provided the input is of interest and is relevant to the learner and is consciously paid attention to by him or her. In order to increase the perceptual salience of the linguistic forms in the input, some researchers (e.g. Sharwood-Smith 1981, Doughty 1991, White 1998) proposed typographical enhancement of these forms through the use of italics, bolding, enlargement and underlining. They argued that this type of enhancement directed learners' attention to the target forms which, according to these researchers, in addition to providing the learner with extensive reading and listening material, would promote acquisition of the target forms.

Another component which is required for successful second language learning is output. Merrill Swain $(1985,1995,2005)$ has argued that comprehensible output (i.e. second language production) also plays an important role in L2 acquisition since it ensures mental grammatical processing and is the most effective stimulus for the development of the learner's interlanguage. Her research into immersion classes taught with content-based second language instruction revealed that despite extended exposure to a target language input, the immersion students' productive ability was far from that of native speakers'. This investigation led Swain to a formulation of her "Output Hypothesis" (1985) in which she put forward the idea that what the learners were lacking were sufficient opportunities for second language production. Swain argued that it is only during the production of the second language (in speech or writing), that the learners can notice that they are not able to say what they want to say in the target language. As Swain stated: "Output may stimulate learners to move from the semantic, open-ended non-deterministic, 
strategic processing prevalent in comprehension to the complete grammatical processing needed for accurate production. Output, thus, would seem to have a potentially significant role in the development of syntax and morphology" (Swain 1995: 128).

One indispensable condition is necessarily present if we are to guarantee the facilitating role of output in L2 acquisition, according to Swain's claim, and that is the "forcing" of the learner to produce language. It means that by motivating the students to carry out special learning tasks requiring interaction and by giving them instant feedback, the teacher is encouraging language production to play the main role.

This paper presents the evidence from a classroom-based, small-scale study of the effect of output on the acquisition of L2, with special reference to modal auxiliary verbs, adjectives and adverbs conveying the meaning of uncertainty. These linguistic items, commonly occurring in academic discourse in English, especially in its written form such as research papers, are components of metadiscourse. Metadiscourse is the term which is given for those lexico-grammatical items by which writers of research papers present both themselves and their arguments, and also it is the language by which they convey their judgements and opinions in a way that opens a dialogue with other researchers who may have alternative opinions. Metadiscourse allows the writer to organize the prose as a coherent piece of text and serves to reveal the writer's relationship to the message presented and also to the reader (Hyland 2004: 109). Modal auxiliary verbs (e.g. may/might, can/could, would, should), adjectives of uncertainty (e.g. likely, possible, probable) and adverbs of uncertainty (e.g. perhaps, possibly, probably) are the "hedges" which withhold the complete commitment of the writer to a presented research, weakening in this way the force of his or her argument in the discourse, and leaving an open space for the reader's response (Hyland 2004, 2005). The knowledge of metadiscourse items by university students will allow them to express their arguments in written and spoken academic texts with appropriate caution and due circumspection, which are the discursive features required by the conventions of Anglo-American academic communities (Hyland 2005: 92-93).

The aim of the present study was to answer the following questions: (1) Which of the three investigated methods for the presentation of the previously mentioned grammatical structures 
is the most effective for adult learners (in this case university students in medicine)? (2) Does the encouragement of learners to produce target-like output (by carrying out special activities) promote the development of the grammatical and rhetorical competence necessary for the learner to be able to create academic discourse of a quality conforming to the recognized academic conventions?

By conducting the above-mentioned comparative study the author of this paper tried, firstly, to find the best method for the acquiring of certain linguistic items by university students and, secondly, to check the effectiveness of output production (as argued by Swain) on SLA by adult learners. The first part of this paper provides information about the role of output and feedback in SLA, and this forms the theoretical foundation for the empirical study, described in the second part of this paper.

\section{Potential roles of output and feedback in second language learning}

Swain's (1985) output hypothesis was formulated as a reaction to Krashen's (1985) input hypothesis and as a reaction against what Swain saw as the inefficacy of the use of comprehensible input alone in the development of learners' linguistic competence in the immersion schools in Canada. As Swain wrote "... the output hypothesis claims that the act of producing language (speaking and writing) constitutes, under certain circumstances, part of the process of second language learning" (Swain 2005: 471).

Overall, five basic functions of output in L2 acquisition were suggested by Swain $(1985,1995,2005)$ :

1. The first function she described was the noticing function, also referred to as the consciousness-raising role. What she meant by this was that when trying to produce the second language, learners notice a gap in their knowledge, and as a result of this, they consciously identify their linguistic errors and lacks of knowledge. This process can stimulate the cognitive generation of new linguistic knowledge or the consolidation of the previously possessed knowledge. In other words, language production involves the using of previously met language items in ways that they have not been used before. 
2. Secondly, she noticed a hypothesis-testing function of output. She observed that the learner's language production is confirmed or modified on the basis of the learner's interaction and the feedback that he or she receives. This hypothesis testing is extremely important in interaction when learners negotiate, either with each other or with their teacher, in an attempt to convey meaning. A fruitful negotiation may lead to a semantic or morphosyntactic modification of output. When feedback is unavailable, the learner checks his or her hypothesis on the basis of the internalized knowledge that he or she possesses about the language.

3. The third function of output that she discerned was a metalinguistic one. Metalanguage is used by learners when they collaboratively try to solve linguistic problems and, as a result, extend these learners' knowledge about the forms and rules of a language. The solving of grammar problems through a study of comprehensible output, with grammatical structures being the targeted topic of conversation, involves a lot of talk about language. This talk contributes to language learning. By encouraging learners to use metalanguage when they encounter linguistic problems during the performance of learning tasks, the teacher is able not only to observe "working" hypotheses about the foreign language, but he or she can also obtain information on various learning strategies which are being used by the learners.

4. Fourthly, Swain saw output as having a function in the development of fluency. She argued that the production of output promotes automatization of language use. Through frequent target language production learners can gain fluency and confidence in L2 use.

5. The fifth function of output, as seen by Swain, was that it enabled learners to move from a semantic to a syntactic use of language. Language use gets learners to move from a stage of comprehension (a semantic use of the language) to a syntactic use of language (when the learner is paying attention to linguistic form $/ \mathrm{s}$ ). For example, the learner noticing that his or her utterance has not been understood by the interlocutor, reformulates it to comply with target language standards.

Comprehensible output production is usually inseparably linked with feedback, which is a kind of interaction providing learners with error correction and with metalinguistic information, facilitating improvement of the accuracy of L2 production. 
In the last 20 years, building on the research of Anderson (1982) and Vygotsky (1978), feedback has been regarded in SLA as being a crucial factor in the encouragement and consolidation of learning.

Feedback is an interaction that makes the learner aware of his or her incorrect use of language, and provides the model for a correct L2 use. Explicit feedback (Birdsong 1989, Gass 1988, White 1991) may take the form of direct correction, e.g. telling the learner that he or she is using the wrong word or the wrong grammatical structure, and following this up with metalinguistic instruction and explanation in how to use the word correctly.

Implicit feedback (Doughty and Varela 1998, Oliver 1995) is a form of indirect correction which includes strategies such as:

- Confirmation checks - the use of expressions to elicit a confirmation that the learner's sentence has been correctly heard or understood (e.g. Is that what you mean?).

- Clarification requests - the use of expressions to elicit a clarification of the utterance (e.g. What did you say?).

- Comprehension checks - the use of expressions to check that an utterance has been understood (e.g. Did you understand?).

- Recasts - the rephrasing of an incorrect utterance using the correct form while still maintaining the original meaning.

Feedback focuses itself on the problematic aspects of the learners' interlanguage and gives them the opportunity to concentrate on their language production and comprehension, which, in turn, helps them to notice any gaps in their knowledge. As Schmidt and Frota suggest "a second language learner will begin to acquire the target-like form if, and only if, it is present in comprehended input and 'noticed' in the normal sense of the word, that is, consciously" (1986: 311).

\section{Study of the role of output and feedback in L2 learning}

While there is general agreement that accuracy is an important goal of L2 teaching, especially in the case of students at the tertiary educational level, it is, however, not clear what 
kind of classroom procedures should be used for the teaching of particular linguistic forms to particular students. Keeping this in mind teachers should constantly be trying to compare the effectiveness of various methods and techniques to find the most suitable means of presentation and practicing of L2 features for their students.

\subsection{The purpose of the study and study design}

In order to find the most effective classroom procedures for enhancing the development of accuracy in the use of some features of metadiscourse (modal auxiliary verbs and some adjectives and adverbs), the study was designed to compare and assess three methods that could be used for the promoting of the acquisition of the target structures. These methods were: (1) explicit instruction provision (DeKeyser 1998, Doughty 1991, Ellis 1991, Lightbown and Pienemann 1993), (2) input enhancement and implicit feedback provision (Lightbown and Spada 1990, White 1991, 1998), and (3) the forcing of learners to produce target-like output (Kowal and Swain 1994, 1997, Swain 1985, 1995, 1998, 2005). factors:

The study described here was motivated by the following

- the fact that the students were having, and had had, problems with the use of modal auxiliary verbs conveying the meaning of probability and logical assumption (e.g. Chronic disease self management program can improve health status ...;The impact of specific interventions could be overestimated; Disease management programmes may not achieve expected effects ...), especially with modal verbs followed by a perfect infinitive "modal+have+past participle" (e.g. The report suggested that the therapy might have affected findings ...; Individuals could have been prescribed more than one drug from each category ...; There might have been some inaccuracy in our estimation of effectiveness ...);

- the realization of the importance for the students to be able to recognize that this type of linguistic items is used by authors of research papers in the field of medicine to distance themselves (hedge) from their claims presented in the paper; 
- the knowledge of the relationship between the form, meaning and function of modal auxiliary verbs as well as adjectives and adverbs of uncertainty is necessary for a correct production of academic texts;

- the students' production of meaningful output enables them to notice the gap in their current use of interlanguage;

- the students' output production gives them an opportunity to discuss, analyse and experiment with the use of new and known L2 structures.

\subsection{Material and method}

The study was carried out over a 4-week period in a regular 2-hour-per-week schedule. The study group included a total of 45 students in the $3^{\text {rd }}$ year of medicine (their mother tongue was Polish). They were the participants of three classes of their obligatory EMP (English for Medical Purposes) course in the Medical College at Jagiellonian University in Krakow. The students represented a B2 level of proficiency in English. These three classes, which constituted three study groups (A, B and C), comprised 14-16 persons each. The linguistic features in focus were elements of metadiscourse whose function in academic discourse was problematic for the students.

The students of all three study groups, working in pairs, were provided with the language corpus, which consisted of selected samples of authentic research articles in the field of medicine that had been published in international scientific journals. These articles had been retrieved online from the university library, and were presented to the students together with a set of language-learning tasks prepared by the teacher. As both "Introduction" and "Discussion" sections of research articles are sections which are densely packed with metadiscourse items (Salager-Meyer 1994), these two sections constituted the main portion of the language input.

There were three different treatment conditions designed for each group:

Group A received the input in a form in which the target metadiscourse elements (hedges) were typographically enhanced by underlining and highlighting them with colour marker-pens. No explicit grammar rule was given, but the stu- 
dents were provided with positive and negative feedback by the teacher, in the form of error correction and metalinguistic explanations.

Group B was provided with the input enhanced in the same manner as for Group A. Explicit rule explanation on the form and function of the target linguistic items was given to the students prior to reading the text and to doing the languagelearning tasks. The feedback obtained from the teacher was in the form of error correction, no metalinguistic explanations were provided during the students' reading the text and doing the tasks that were assigned to them after the reading had been finished.

Group $\mathrm{C}$ received non-enhanced input, and before reading the text and doing the tasks the students performed a dictogloss (overall four dictogloss sessions). In the dictogloss activity (Swain 1998, Wajnryb 1989), a short, specially adapted research article, dense with target forms was read twice to the students. When it was read for the first time, the students were asked to listen to the passage. During the second reading the students were allowed to take notes to help them reconstruct the text. Then the students worked in pairs or small groups to reconstruct a dictogloss text (for 25-30 minutes) from their shared notes. The students' performance of the task was observed by the teacher, who approached each pair and provided them with corrective and explicit metalinguistic feedback. The purpose of the teacher's feedback was to draw attention to particular grammatical forms and to heighten the students' awareness about the structural and functional aspects of hedges and other linguistic items that were necessary for carrying out dictogloss and language-learning tasks. Finally, the reconstructed texts were compared between the pairs, and also with the original dictogloss passage, in a whole-class context.

It should also be noted that before hearing the dictogloss passage (Group $\mathrm{C}$ ), and before reading the text and doing the language-learning tasks (Groups A and B), the unknown vocabulary was explained by the teacher and the topic of the text was discussed by the students through a brainstorming activity.

The table below shows the required tasks of the learners and the teacher for every step of the dictogloss activity. 
Table 1. Steps for dictogloss activity (source: Nation and Newton 2009: 68)

\begin{tabular}{|l|l|l|}
\hline Step & Students & Teacher \\
\hline 1. Preparation & $\begin{array}{l}\text { Vocabulary study to prepare for the test. } \\
\text { Discuss the topic (predict vocabulary and } \\
\text { content etc.) }\end{array}$ \\
\hline $\begin{array}{l}\text { 2. Listening for } \\
\text { meaning }\end{array}$ & $\begin{array}{l}\text { Listen to the whole } \\
\text { text }\end{array}$ & $\begin{array}{l}\text { Reads the text at nor- } \\
\text { mal speed }\end{array}$ \\
\hline $\begin{array}{l}\text { 3. Listening and note- } \\
\text { taking }\end{array}$ & $\begin{array}{l}\text { Take notes listing key } \\
\text { words }\end{array}$ & $\begin{array}{l}\text { Reads again at nor- } \\
\text { mal speed }\end{array}$ \\
\hline $\begin{array}{l}\text { 4. Text reconstruction } \\
\text { in groups }\end{array}$ & $\begin{array}{l}\text { Work in groups to } \\
\text { reconstruct an ap- } \\
\text { proximation of the } \\
\text { text from notes }\end{array}$ & Helps groups \\
Offers guidance \\
\hline $\begin{array}{l}\text { 5. Text comparison } \\
\text { between groups }\end{array}$ & $\begin{array}{l}\text { Compare group ver- } \\
\text { sions of the text. Pay } \\
\text { attention to points } \\
\text { of usage that emerge } \\
\text { from the discussion }\end{array}$ & $\begin{array}{l}\text { Facilitates class com- } \\
\text { parison of versions } \\
\text { from different groups. } \\
\text { Facilitates discussion } \\
\text { and correction of } \\
\text { errors }\end{array}$ \\
\hline
\end{tabular}

It is worth noticing that steps 4 and 5 direct the learners' attention to language form (i.e. word forms, word order, grammar rules etc.) after having been exposed to the meaning-focused listening in steps 2 and 3.

The set of language-learning tasks, which all the three groups performed during and after reading the text, included the following activities (adapted from Channel 1994, Hyland 2005, Salager-Meyer 1994):

- Ranking the sentences in terms of the strength of the writer's claim;

- Choosing the hedges for filling the gaps to weaken the author's claim;

- Identifying the examples of hedges in the text, and assigning meaning to them;

- Distinguishing between statements in the text which report facts and those which express opinions;

- Adding or removing all hedges from the text and noticing the effect this has on it;

- Gap-filling exercise - inserting an appropriate metadiscourse 
item in the gapped text;

- Transforming a spoken text, such as a lecture, into an essay, including the indicated hedging devices;

- Changing a non-academic text from a popular science magazine into an academic text for a scientific journal, and discussing what changes should be made;

- Translating a text in Polish into English for a similar academic community, and comparing the use of hedges in the two languages;

- Conducting an analysis of a self-chosen research article from the point of view of the hedges used in them and their rhetorical function in the text;

- Writing an essay entitled "The relation between smoking and lung cancer".

In order to assess the long-term effectiveness of the three treatment procedures aiming to help the students gain accuracy in using hedges, all the groups underwent a pre-test prior to the experiment, an immediate post-test just after finishing the experiment, and a remote post-test 2 months after the experiment. The pre-test comprised the following tasks: gap-filling, multiple choice questions and the ranking of metadiscourse items according to their strength. The post-tests involved a set of tasks such as multiple-choice, gap-filling, correction of sentences, translation from Polish into English, and the ranking of sentences according to the strength of the assertiveness of the presented information in them.

\subsection{Results}

The effectiveness of these three approaches to teaching modal verbs and some adjectives and adverbs was assessed by two tests: an immediate post-test (immediately after finishing the teaching session) and a remote post-test 2 months later.

On immediate tests based on multiple-choice and gap filling tasks groups $\mathrm{A}$ and $\mathrm{C}$ performed similarly, but on remote tests, especially those requiring manipulation with the texts such as conversion of a non-academic text into an academic text in which hedges should be used to present the authors' claims in a cautious way, group C outperformed both groups A and B. 
The results presented in Figure 1 show the total score obtained in the tasks performed at these tests, expressed in the percentage of the maximum score.

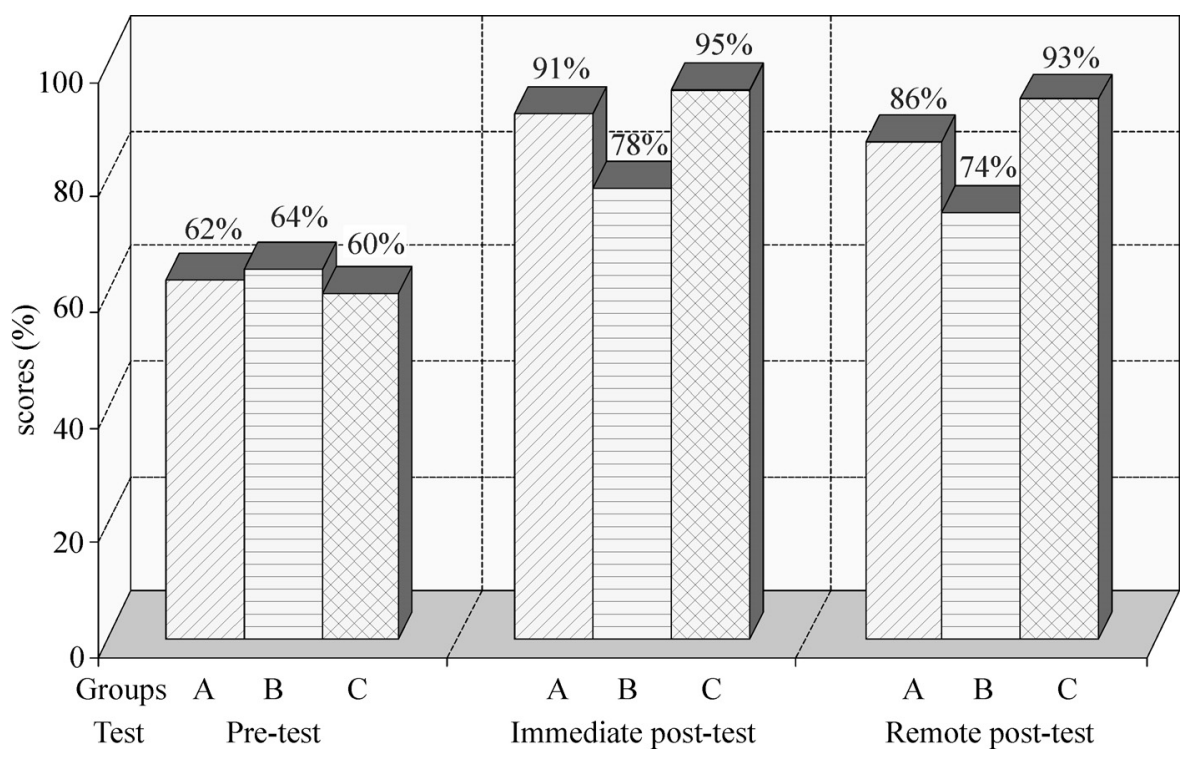

Figure 1. Results of the tests.

Pre-test: Group A: 62\%; Group B: 64\%, Group C: 60\% Immediate post-test: Group A: 91\%; Group B: 78\%, Group C: 95\% Remote post-test: Group A: 86\%; Group B: 74\%, Group C: 93\%

\section{Discussion}

The contribution of output to second language acquisition is still a subject for debate since it has not been sufficiently documented in the literature concerning the whole subject of L2 acquisition (Shehadeh 2002). The research that has been carried out into the role of "pushed" output in second language vocabulary acquisition seems to show benefits more clearly than in the case of second language grammar acquisition. For example, De la Fuente (2002), Ellis and He (1999), Swain and Lapkin $(1995,1998)$ have observed a direct positive relation between the learner's frequency of exposure to output and second lan- 
guage vocabulary development. When teaching vocabulary to students who were at a low level of proficiency in the language, Ellis and He (1999) found that the group of learners who were required to give instructions and explanations to an interlocutor outperformed at subsequent post-tests the groups who were not required to produce language but only performed learning activities, such as matching words with pictures, matching words with definitions, labelling pictures, etc. Similarly, De la Fuente's study (2002) has shown that an "output" group received higher scores at post-tests than a "non-output" group, as far as production of vocabulary was concerned. However, when reception of vocabulary was assessed, all groups achieved a similar level.

The results of the investigations into the contribution of a "forced" output to the development of grammar accuracy in second language learners have not been unequivocal. Nobuyoshi and Ellis (1993) investigated to see whether there had been any improvement in the grammatical accuracy of second language learners' utterances in a small-scale study of the learning of the English past tense. These researchers noticed that encouraging English language learners to modify their output by means of clarification requests led to increased accuracy in the using of these past tense forms. Izumi and Bigelow (2000) studied the influence of "forced" output in the learning of third conditional clauses in English. The experimental groups, who had to generate written texts similar to those they had been presented with as their input, considerably improved the accuracy of their writing during the experiment, but at post-tests, which focused on the use of target grammar structures, both experimental and control groups performed similarly. Analogical results were also obtained by Izumi et al. (1999) in their study about the acquisition of relative clauses. The comparison of the results obtained by the experimental "output" group with the "non-output" group showed no differences between the studied groups. Although the output task was also a production task, it did not promote acquisition of the target form.

The results obtained from our experiment seem to be inconsistent with the results obtained by Izumi and Bigelow (2000), and by Izumi et al. (1999) since in the immediate post-test, the "output" group (Group C) and one of the "non-output" groups (Group A) obtained similar mean scores, but on the remote posttest the "output" group (Group C) quite noticeably outperformed both "non-output" groups. 
Although some researchers, e.g. Ellis (2001), Mitchell and Myles (2004), Shehadeh (2002), state that the benefits of "pushed" output remain somewhat elusive and hard to demonstrate since there is still a severe lack of data proving that learner's "pushed" output has any effect on second language learning, the results of our study seem to show a beneficial role for "pushed" output in achieving a greater long-term accuracy in the use of modal verbs, adjectives and adverbs that convey meanings of uncertainty in the expressing of opinions and in the presenting of a certain authorial distance from the proposition. Our observation of the performance of the students' text reconstruction tasks showed that at first the students were more concerned with producing a coherent text than with attention to the target forms. After the teacher had directed their attention to the target forms, the students started to notice them and use these forms in the reconstructed text more often. It should be noted that the students in all our three study groups were on the intermediate level of L2 proficiency, and the target forms had not been totally new for at least some of them. However, the pre-test showed that these target forms had not been adequately mastered by them, especially when they were required to use them in a sociolinguistically appropriate manner. Although our study was conducted on a small scale, it provides some evidence supporting the role of output in SLA, this being an especially important role in the effective development of long-term accuracy in the use of grammar forms in texts generated by them according to accepted academic standards.

\section{Conclusion}

The results of the above-presented study suggest that the procedure of "forcing" students to produce meaningful output can be an effective source of long-lasting grammatical and rhetorical accuracy. It means that dictogloss sessions during which students were required to produce comprehensible output and check their hypotheses about the L2 may be useful in heightening students' awareness of grammatical and rhetorical aspects of research articles in the context of teaching ESP. Performing dictogloss activities combined with the teacher's explicit feedback provision, students were engaged in target language production, which focused their atten- 
tion not only on vocabulary, morphology and syntactic structures, but also on rhetorical conventions used in an academic context. Moreover, the results of this study seem to indicate that supplying metalinguistic explanatory feedback during the students' task performance (Groups A and C) facilitates the learning of grammatical structures better than providing grammar rules prior to carrying out learning activities with no explicit feedback (Group B).

The results of the above-described investigation seem to indicate the potential role of the combination of three factors in the promotion of long-term second language grammar competence. These factors are:

1. Comprehensible output production stimulated by dictogloss, which allows students to check their hypotheses about the L2, notice the gap in their current linguistic knowledge, and acquire fluency in target language production;

2. Explicit awareness-raising tasks, which develop the grammatical and rhetorical competence necessary for language production;

3. Teacher's explicit feedback during dictogloss activity and language-learning tasks, which provided error correction and metalinguistic explanations on the structure and function of the linguistic items in question.

Since the number of students investigated was insufficient to provide convincing quantitative evidence, it is necessary to carry out a study including a larger number of participants. The results from this type of research would give ESP teachers information which could be utilized in their task of the preparation of effective language presentation and language-learning activities. The benefits from this would be not only the raising of students' linguistic and rhetorical consciousness, but also the developing of their fluency and confidence in the use of the target language.

\section{Address:}

Ewa Donesch-Jezo

Department of Foreign Languages

Jagiellonian University

Os. Kolorowe 22/37

31-940 Krakow

Poland

E-mail: ewadj@op.pl 


\section{References}

Anderson, John R. (1982) “Acquisition of cognitive skill”. Psychological Review 89, 369-406.

Birdsong, David (1989) Metalinguistic performance and interlinguistic competence. New York: Springer.

Channel, Joanna (1994) Vague language. Oxford: Oxford University Press.

De la Fuente, Marı José (2002) "Negotiation and oral acquisition of L2 vocabulary”. Studies in Second Language Acquisition 24, 1, 81-112.

DeKeyser, Robert (1998) "Beyond focus on form: cognitive perspectives on learning and practicing second language grammar". In Catherine Doughty and Jessica Williams, eds. Focus on form in classroom second language acquisition, 42-63. New York: Cambridge University Press.

DeKeyser, Robert (2007) "Skill acquisition theory". In Bill VanPatten and Jessica Williams, eds. Theories in second language acquisition: an introduction, 97-113. Mahwah, NJ: Erlbaum.

Doughty, Catherine (1991) "Second language instruction does make a difference: evidence from an empirical study on SL relativization". Studies in Second Language Acquisition 13, 4, 431-469.

Doughty, Catherine and Elizabeth Varela (1998) "Communicative focus on form". In Catherine Doughty and Jessica Williams, eds. Focus on form in classroom second language acquisition, 114-139. Cambridge: Cambridge University Press.

Ellis, Rod (1991) "Grammar teaching - practice or consciousness-raising?" In Rod Ellis, ed. Second language acquisition and second language pedagogy, 232-241. Clevedon, Avon: Multilingual Matters.

Ellis, Rod (1997) Second language acquisition. Oxford: Oxford University Press.

Ellis, Rod (2001) "Methodological options in grammar teaching materials". In Eli Hinkel and Sandra Fotos, eds. New perspectives on grammar teaching in second language classrooms. Mahwah, NJ: Lawrence Erlbaum.

Ellis, Rod and Xien He (1999) "The roles of modified input and output in the incidental acquisition of word meanings". Studies in Second Language Acquisition 21, 2, 285-301.

Gass, Susan M. (1988) "Integrating research areas: a framework for second language studies". Applied Linquistics 9, 2, 198-217.

Gass, Susan M. and Alison Mackey (2007). "Input, interaction and output in second language learning”. In Bill VanPatten and Jessica Williams, eds. Theories in second language acquisition: an introduction, 175-200. Mahwah, NJ: Erlbaum.

Hyland, Ken (2004) Disciplinary discourses: social interactions in academic writing. 2nd ed. Michigan: The University of Michigan Press. 


\section{Ewa Donesch-Jezo}

Hyland, Ken (2005) Metadiscourse: exploring interaction in writing. London: Continuum.

Izumi, Shinichi and Martha Bigelow (2000) "Does output promote noticing and second language acquisition?” TESOL Quarterly 34, 2, 329-378.

Izumi, Shinichi, Martha Bigelow, Miho Fujiwara, and Sarah Fearnow (1999) "Testing the output hypothesis: effects of output on noticing and second language acquisition”. Studies in Second Language Acquisition 21, 3, 421-452.

Kowal, Maria and Merrill Swain (1994) "Using collaborative language production tasks to promote students' language awareness". Language Awareness 3, 2, 73-93.

Kowal, Maria and Merrill Swain (1997) "From semantic to syntactic processing: how can we promote metalinguistic awareness in the French immersion classroom?" In Robert Keith Johnson and Merrill Swain, eds. Immersion education: international perspectives, 284-309. New York: Cambridge University Press.

Krashen, Stephen D. (1982) Principles and practice in second language acquisition. London: Pergamon.

Krashen, Stephen D. (1985) The input hypothesis: issues and implications. New York: Longman.

Krashen, Stephen D. (1998) “Comprehensible output?” System 26, 175-182.

Lightbown, Patsy M. and Manfred Pienemann (1993) "Comments on Stephen D. Krashen's 'Teaching issues: formal grammar instruction'”. TESOL Quarterly, 27, 4, 717-722.

Lightbown, Patsy M. and Nina Spada (1990) "Focus on form and corrective feedback in communicative language teaching: effects on second language learning". Studies in Second Language Acquisition 12, 4, 429-448.

Mitchell, Rosamond and Florence Myles (2004) Second language learning theories. 2nd ed. London: Arnold.

Nation, I.S.P. and Jonathan Newton (2009) Teaching ESL/EFL Listening and Speaking. New York, London: Routledge.

Nobuyoshi, Junko and Rod Ellis (1993) "Focused communication tasks and second language acquisition”. ELT Journal 47, 3, 203-210.

Oliver, Rhonda (1995) "Negative feedback in child NS-NNS conversation". Studies in Second Language Acquisition 17, 4, 459-481.

Pica, Teresa, Richard Young, and Catherine Doughty (1987) "The impact of interaction on comprehension". TESOL Quarterly 21, 4, 737-758.

Salager-Meyer, Françoise (1994) "Hedges and contextual communicative function in medical English: written discourse". Journal of English for Specific Purposes 13, 2, 149-170. 
Schmidt, Richard and Sylvia Frota (1986) "Developing basic conversational ability in a second language: a case study of an adult learner of Portuguese”. In Richard R. Day, ed. Talking to learn: conversation in second language acquisition, 237-326. Rowley, MA: Newbury House.

Sharwood-Smith, Michael (1981) "Consciousness-raising and second language acquisition theory". Applied Linguistics 2, 2, 159-168.

Sharwood-Smith, Michael (1993) "Input enhancement in instructed SLA: theoretical bases". Studies in Second Language Acquisition 15, 2, 165-179.

Shehadeh, Ali (2002) "Comprehensible output, from occurrence to acquisition: an agenda for acquisitional research". Language Learning 52, 3, 597-647.

Swain, Merrill (1985) “Communicative competence: some roles of comprehensible input and comprehensible output in its development". In Susan M. Gass and Carolyn G. Madden, eds. Input in second language acquisition, 235-253. Rowley, MA: Newbury House.

Swain, Merrill (1995) "Three functions of output in second language learning”. In Guy Cook and Barbara Seidlhofer, eds. Principle and practice in applied linguistics, 125-144. Oxford: Oxford University Press.

Swain, Merrill (1998) "Focus on form through conscious reflection". In Catherine Doughty and Jessica Williams, eds. Focus on form in classroom second language acquisition, 64-82. Cambridge: Cambridge University Press.

Swain, Merrill (2005) "The output hypothesis: theory and research". In Eli Heinkel, ed. Handbook of research in second language teaching and learning, 471-483. Mahwah, NJ: Lawrence Erlbaum Associates.

Swain, Merrill and Sharon Lapkin (1995) "Problems in output and the cognitive processes they generate: a step towards second language learning”. Applied Linguistics 16, 3, 371-391.

Swain, Merrill and Sharon Lapkin (1998) "Interaction and second language learning: two adolescent French immersion students working together". Modern Language Journal 82, 3, 320-337.

VanPatten, Bill and Jessica Williams (2007) Theories in second language acquisition. London: Lawrence Erlbaum Associates, Publishers.

Vygotsky, Lev S. (1978) Mind in society: the development of higher psychological processes. Cambridge, MA: Harvard University Press.

Wajnryb, Ruth (1989) "Dicto-gloss: a text-based communicative approach to teaching and learning grammar". English Teaching Forum 27, 4, 16-29.

White, Joanna (1998) “Getting the learners' attention: a typographical input enhancement study". In Catherine Doughty and Jessica Williams, eds. Focus on form in classroom second language acquisition, 85-113. Cambridge: Cambridge University Press. 
White, Lydia (1991) “Adverb placement in second language acquisition: some effects of positive and negative evidence in the classroom". Second Language Research 7, 2, 133-161.

\begin{abstract}
Kokkuvõte. Ewa Donesch-Jezo: Väljundi ja tagasiside roll teise keele omandamisel: keeletunnipõhine uurimus täiskasvanud inglise keele õppijate grammatika omandamisest. Alates 1960. aastate algusest on teise keele omandamist uurinud väga paljud õpetajad ja teadlased. Üks teise keele omandamisega seotud teemadest on olnud meetodi leidmine, mis suunaks õppija keskendama oma tähelepanu sihtkeele vormile. Selle saavutamiseks on välja pakutud mitmeid teooriad ja meetodeid, alustades kaudsematest ja lõpetades konkreetsemate võimalustega. Kuigi igal väljapakutud meetodil on oma eelised, ei ole neist senini piisanud, et panna õppijaid märkama lõhet nende enda vahekeele vormide ja sihtkeele vormide vahel. Swain $(1995,1998)$ on väitnud, et peale selle, et õppijatele antakse arusaadav sisend, täidab teise keele omandamisel tähtsat rolli ka arusaadav väljund. Kui julgustada õppijaid rääkima ja kirjutama teises keeles ning luua neile selleks võimalusi, märkavad nad, et ei ole suutelised ütlema seda, mida nad sihtkeeles öelda sooviks. Swaini hüpoteesi põhjal väljundi kohta eeldatakse, et kui julgustada täiskasvanud õppijaid (üliõpilasi) moodustama sihtkeele moodi väljundeid, soodustab see akadeemiliste testide tegemiseks vajalike grammatiliste oskuste omandamist. Uurimustöö eesmärk on keeletunnis läbi viidud väiksemahulise uuringu abil näidata väljundi mõju õppijale teise keele ebakindlust väljendavate modaaltegusõnade, omadussõnade ja määrsõnade omandamisel. Kõik need sõnaliigid on olulised metadiskursuse osad. Uuringu tulemused näitasid, et selline lähenemine, kus õppijaid julgustati tekitama arusaadavat väljundit koos õpitu kinnistamise eest hoolitsemisega, mis tagati sobiva tagasisidega, võib olla tõhus viis kestva grammatilise täpsuse saavutamiseks õppijate sihtkeeles.
\end{abstract}

Märksõnad: teise keele omandamine, tagasiside, grammatiline täpsus, metadiskursus, teadlikkuse tõstmine 